\title{
PROSES PEMBUATAN SERBUK LOGAM DENGAN METODA ATOMISASI LAS OKSI-ASITILEN
}

\author{
Muhammad Ridlwan 1), Alva Edy Tontowi 2), Heru Santoso B.R 2) \\ 1) Jurusan Teknik Mesin, Universitas Islam Indonesia \\ Yogyakarta, E-mail : ridlwannur@yahoo.com \\ 2) Program Studi Teknik Mesin, Universitas Gadjah Mada \\ Yogyakarta, E-mail : menaet@ugm.ac.id
}

\begin{abstract}
Atomization is the most common method for producing powders from metal. There are three atomization methods in powder fabrication : water atomization, gas atomization, and centrifugal atomization. Atomization was being developed to increase powder quality and process productivity. A new atomization method is possible to find by using another energy resources. Oxy-acetylene can be used as an energy resource in atomization.

In this research, powders are made by oxy-acetylene atomization method. Material in wire form is melted in oxy-acetylene flame, which has operating temperature around $3480^{\circ} \mathrm{C}$, and atomized to form a fine spray. The fine molten droplets rapidly solidify forming a powders. This research investigate the variation of wire diameter and flame gun attacking angle on atomization process efficiency and production rate. Wire material which used in this research is commercial steel wire with $0.75 \mathrm{~mm} ; 1.25 \mathrm{~mm} ; 1.50 \mathrm{~mm}$ in diameter. Flame gun attacking angle is varied $25^{\circ}, 30^{\circ}, 35^{\circ}, 40^{\circ}$, and $45^{\circ}$.

Result shows that oxy-acetylene atomization method can be used to produce metal powders. The characteristic of powders which produced by this atomization method have spherical shape, $75 \mu \mathrm{m}-90 \mu \mathrm{m}$ in size, oxidized, and carburized. The efficiency and production rate of the atomization process are around $12.2 \%$ and $0.1429 \mathrm{gram} / \mathrm{minute}$. This efficiency and production rate are influenced by wire diameter. Bigger wire diameter results higher efficiency, but lower production rate. For $1.25 \mathrm{~mm}$ diameter of commercial wire steel, an optimum efficiency of atomization process, $15.1 \%$, are resulted by $30^{\circ}$ of flame gun attacking angle.
\end{abstract}

Keywords : powder fabrication, oxy-acetylene atomization method

\section{PENDAHULUAN}

Salah satu metoda yang sering digunakan untuk membuat serbuk secara massal adalah metoda atomisasi. Beberapa metoda atomisasi yang telah dikenal adalah metoda atomisasi air, metoda atomisasi gas, dan metoda atomisasi sentrifugal. Metoda atomisasi gas dan atomisasi sentrifugal dapat menghasilkan serbuk berukuran kecil dan berbentuk bola (spherical). Serbuk dengan ukuran kecil dan bentuk bola ini bagus digunakan untuk pembuatan produk dengan proses metalurgi serbuk karena dapat menghasilkan produk dengan porositas kecil. Peralatan dan biaya operasional proses atomisasi gas dan atomisasi sentrifugal relatif mahal, maka diperlukan metoda atomisasi baru yang lebih murah dan dapat menghasilkan serbuk dengan ukuran yang kecil dan memiliki bentuk bola. 
Teknik penggunaan sumber energi-energi yang lain memungkinkan ditemukannya metoda-metoda atomisasi baru.

Las oksi-asitilen atau sering disebut las karbit merupakan salah satu teknologi pengelasan yang relatif murah, baik dari segi peralatannya maupun operasionalnya. Las oksi-asitilen ini dapat digunakan sebagai sumber energi proses atomisasi serbuk logam karena memiliki temperatur yang cukup tinggi yaitu kurang lebih $3480^{\circ} \mathrm{C}$ pada inti nyala las. Tujuan dari penelitian ini adalah meneliti pembuatan serbuk logam dengan metoda atomisasi menggunakan sumber energi las oksi-asitilen dan mengetahui karakteristik serbuk logam yang dihasilkan dari metoda atomisasi menggunakan sumber energi las oksi-asitilen.

\section{TINJAUAN PUSTAKA}

Karakteristik serbuk yang dihasilkan dari metoda atomisasi air memiliki bentuk tak beraturan atau irregular [3,4,5], permukaan kasar karena terjadi oksidasi, dan berpori [17]. Untuk menghasilkan serbuk yang lebih halus maka kecepatan pancaran air (water jets) diperbesar.

Dalam metoda atomisasi gas, semakin besar energi yang diberikan kepada logam cair maka akan dihasilkan serbuk yang lebih halus [3]. Semakin tinggi temperatur logam cair maka serbuk yang dihasilkan semakin halus [8]. Penggunaan atmosfer gas inert pada proses atomisasi dapat meningkatkan efektivitas proses disintegrasi logam cair dengan cara melindungi droplet dari oksidasi [13].

Proses semburan logam panas (metal flame spray process) adalah salah satu teknik pelapisan logam (coating) yaitu dengan cara menyemburkan logam cair ke permukaan benda kerja yang akan dilapisi [16]. Energi yang digunakan dalam proses ini berasal dari pembakaran kimiawi atau busur listrik untuk mencairkan, atau menghaluskan, dan mempercepat droplet atau partikel halus hingga kecepatan berkisar 50 sampai dengan 1000 m/s. Shi dan Hwang [15] menyatakan nyala plasma pada semburan panas dapat mencapai temperatur $7000-14.000^{\circ} \mathrm{K}$, jauh di atas titik leleh semua material. Partikel dengan temperatur dan kecepatan tinggi tersebut dapat menghasilkan deformasi droplet yang cukup besar pada saat berbenturan dengan permukaan benda yang dilapisi [1]

Beberapa teknologi yang digunakan dalam proses semburan panas, yaitu : nyala oksi-asitilen, busur listrik, dan busur plasma. Aplikasi teknologi proses semburan panas adalah untuk perlindungan terhadap korosi [7]. Bentuk bahan baku dari logam pelapis dapat berupa kawat (wire) atau serbuk (powder). Bentuk serbuk yang bagus digunakan sebagai bahan baku proses semburan panas adalah bentuk bola, karena memiliki sifat mampu-alir yang tinggi dan kondisi yang optimal pada saat partikel dicairkan dan disemprotkan [11]. Jika bentuk bahan baku berupa kawat, maka proses ini sering disebut dengan wire spray atau wire metallizing. Pada proses semburan panas, penggunaan kawat sebagai bahan baku lebih ekonomis daripada bahan baku berbentuk serbuk [9].

Proses semburan kawat oksi-asitilen (oksi-asitylene wire spray) adalah proses pelapisan logam dengan semburan panas dengan sumber energi nyala oksi-asitilen dan bentuk bahan baku logam pelapis berupa kawat. Salah satu keuntungan dari 
proses semburan panas ini adalah banyaknya jenis material yang dapat digunakan dalam proses ini [12]. Prinsip kerja dari proses semburan kawat oksi-asitilen ini adalah sebagai berikut : material pelapis yang berbentuk kawat dilewatkan ke dalam nyala oksi-asitilen, yang mempunyai temperatur operasi kurang lebih $3480^{\circ}$ $\mathrm{C}$, dipanaskan hingga mencair. Kemudian pada saat yang sama udara bertekanan tinggi dialirkan ke kawat yang sedang mencair tersebut untuk mengatomisasi logam cair dan memperbesar kecepatan semburan (spray jet).

Partikel logam cair yang disemprotkan dari nosel mempunyai ukuran diameter 0,0001 - 0,00015 inchi pada jarak penyemprotan optimum yaitu antara 4 10 inchi [10]. Semburan ini kemudian menabrak permukaan benda kerja sehingga terjadi ikatan antara logam cair dangan permukan benda kerja, membentuk lapisan logam. Pada lapisan ini terdapat porositas, oksidasi [2], dan retakan pada mikrostrukturnya [14,6].

Pada penelitian ini, semburan logam cair yang telah teratomisasi tersebut tidak ditabrakkan ke permukaan benda kerja, namun dibiarkan membeku sehingga terbentuk partikel.

\section{METODOLOGI PENELITIAN}

\subsection{Bahan dan Peralataan Penelitian}

Bahan baku yang digunakan untuk membuat serbuk dalam penelitian ini adalah kawat baja komersial dengan diameter 0,75 mm, 1,25 mm, dan 1,50 mm. Dimensi kawat yang digunakan dalam penelitian ini dapat dilihat pada Tabel 3.1 di bawah ini :

Tabel 1. Dimensi bahan baku kawat

\begin{tabular}{|c|c|c|c|}
\hline $\begin{array}{c}\text { Diameter Kawat } \\
(\mathrm{mm})\end{array}$ & $\begin{array}{c}\text { Berat per Meter } \\
(\mathrm{gr} / \mathrm{m})\end{array}$ & $\begin{array}{c}\text { Panjang Kawat } \\
(\mathrm{m})\end{array}$ & $\begin{array}{c}\text { Berat Awal } \\
(\mathrm{gr})\end{array}$ \\
\hline 0,75 & 5,06 & 10 & 50,60 \\
\hline 1,25 & 10,09 & 5 & 50,45 \\
\hline 1,50 & 17,00 & 3 & 51,00 \\
\hline
\end{tabular}

Peralatan yang digunakan dalam penelitian adalah peralatan atomisasi las oksi-asitilen seperti pada Gambar 1, peralatan uji ayakan atau sieve analysis mesh, peralatan uji komposisi kimia dengan peralatan difraksi sinar-X dengan mesin XRD-6000 Shimadzu X-Ray Diffractometer, dan peralatan SEM. 


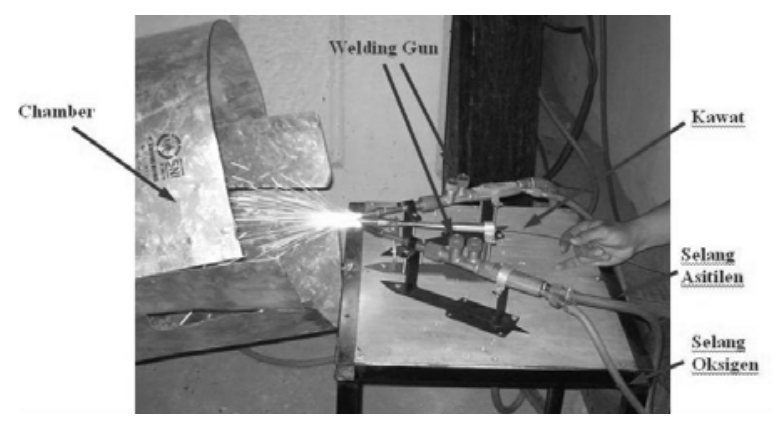

Gambar 1. Peralatan Atomisasi Las Oksi-Asitilen

\subsection{Cara Penelitian}

Langkah-langkah penelitian dapat dilihat pada Gambar 2. di bawah ini :

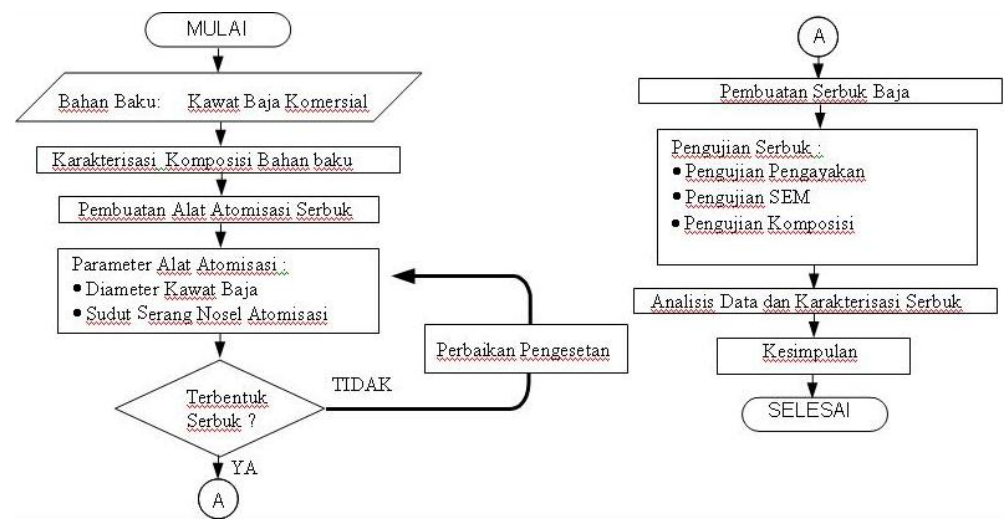

Gambar 2. Diagram Alir Penelitian

Beberapa parameter dalam proses atomisasi las oksi-asitilen adalah diameter kawat, kecepatan pemakanan kawat (feedrate), jumlah nosel las yang digunakan, jenis nyala api las oksi-asitilen, dan sudut serang. Sudut serang adalah sudut yang dibentuk oleh nosel las dengan kawat. Parameter-parameter proses atomisasi yang diteliti dalam penelitian ini adalah diameter kawat dan sudut serang. Karakterisasi partikel serbuk yang dilakukan dalam penelitian ini meliputi distribusi berat ukuran partikel serbuk, bentuk partikel serbuk, dan komposisi kimia serbuk hasil proses atomisasi.

\section{HASIL PENELITIAN}

\subsection{Proses Atomisasi dengan Variasi Diameter Kawat}

Dalam penelitian ini, parameter yang divariasikan adalah diameter kawat, yaitu untuk diameter kawat 0,75 mm, 1,25 mm, dan 1,50 mm. Sedangkan untuk parameter-parameter yang lain dibuat tetap yaitu sebagai berikut : jumlah nosel las 2 buah, kecepatan pemakanan kawat $2,78 \mathrm{~mm} /$ detik, jenis nyala api las nyala netral, dan sudut serang $45^{\circ}$. Hasil pengujian ayakan dari serbuk hasil proses 
atomisasi las oksi-asitilen dengan variasi diameter kawat ini seperti pada Tabel 2 berikut ini :

Tabel 2. Hasil pengujian pengayakan untuk proses atomisasi las oksi-asitilen dengan variasi diameter kawat

\begin{tabular}{|c|c|c|c|c|c|c|c|}
\hline \multicolumn{2}{|c|}{ Ukuran Ayakan } & \multicolumn{2}{c|}{$\phi$ kawat $=0.75 \mathrm{~mm}$} & \multicolumn{2}{c|}{$\phi$ kawat $=1.25 \mathrm{~mm}$} & \multicolumn{2}{c|}{$\phi$ kawat $=1.50 \mathrm{~mm}$} \\
\hline $\begin{array}{c}\text { Sieve } \\
\text { Size }\end{array}$ & $\begin{array}{c}\text { Diameter lubang } \\
(\text { mikron})\end{array}$ & $\begin{array}{c}\text { berat } \\
(\text { gram })\end{array}$ & $\begin{array}{c}\text { kumulatif } \\
(\%)\end{array}$ & $\begin{array}{c}\text { berat } \\
(\mathrm{gram})\end{array}$ & $\begin{array}{c}\text { kumulatif } \\
(\%)\end{array}$ & $\begin{array}{c}\text { berat } \\
(\mathrm{gram})\end{array}$ & $\begin{array}{c}\text { kumulatif } \\
(\%)\end{array}$ \\
\hline$>300$ & $<50$ & 0.70 & 24.8 & 0.30 & 13.4 & 0.20 & 16.7 \\
\hline 300 & 50 & 0.25 & 33.7 & 0.60 & 40.2 & 0.30 & 41.7 \\
\hline 270 & 53 & 0.11 & 37.6 & 0.26 & 51.8 & 0.10 & 50.0 \\
\hline 200 & 75 & 0.70 & 62.4 & 0.13 & 57.6 & 0.10 & 58.3 \\
\hline 170 & 90 & 0.36 & 75.2 & 0.89 & 97.3 & 0.40 & 91.7 \\
\hline 140 & 106 & 0.70 & 100.0 & 0.06 & 100.0 & 0.10 & 100.0 \\
\hline \multicolumn{2}{|c|}{} & 2.82 & & 2.24 & & 1.20 & \\
\hline
\end{tabular}

Grafik efisiensi dan laju produksi dari proses atomisasi las oksi-asitilen dengan variasi diameter kawat dapat dilihat pada Gambar 3 dan Gambar 4. Ratarata efisiensi proses atomisasi ini masih relatif rendah yaitu $4.12 \%$ karena banyak logam cair yang menetes tidak menjadi serbuk. Ada beberapa kemungkinan yang menyebabkan banyaknya logam cair yang menetes, yaitu : pertama, diameter kawat yang besar juga menyebabkan banyak logam cair yang menetes. Kedua, kawat terpanaskan lebih dahulu sebelum mencapai titik atomisasi karena terpengaruh oleh radiasi panas dari nyala las.

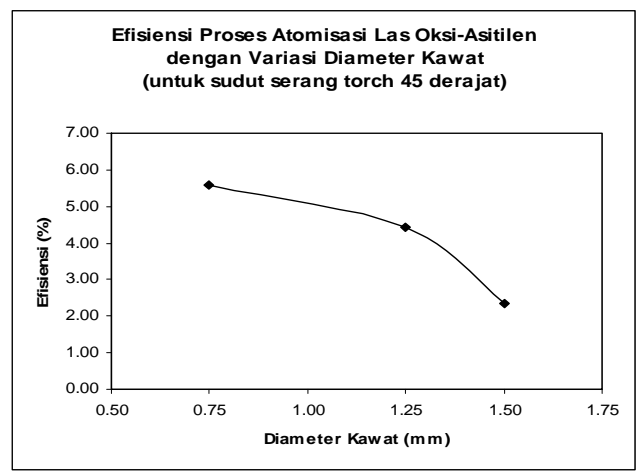

Gambar 3. Efisiensi proses atomisasi dengan variasi diameter kawat

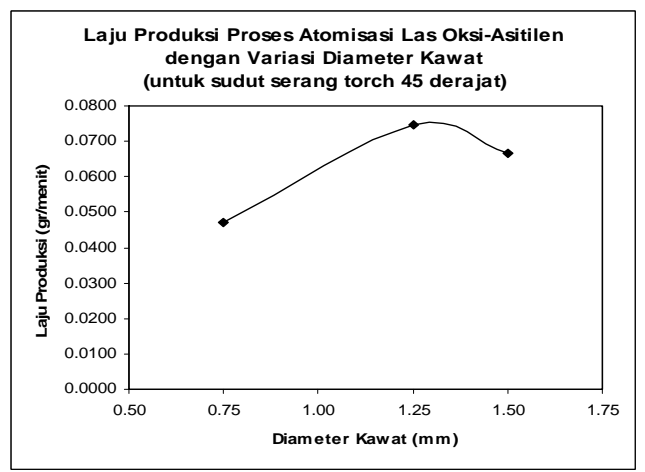

Gambar 4. Laju produksi proses atomisasi dengan variasi diameter kawat

Berdasarkan hasil pengujian ayakan dari serbuk yang dihasilkan dari proses atomisasi dengan variasi diameter kawat, seperti pada Tabel 2, kemudian dibuat distribusi persen ukuran partikel menggunakan fungsi distribusi Rosin-RammlerSperling (RSS), seperti pada Gambar 5 di bawah ini: 


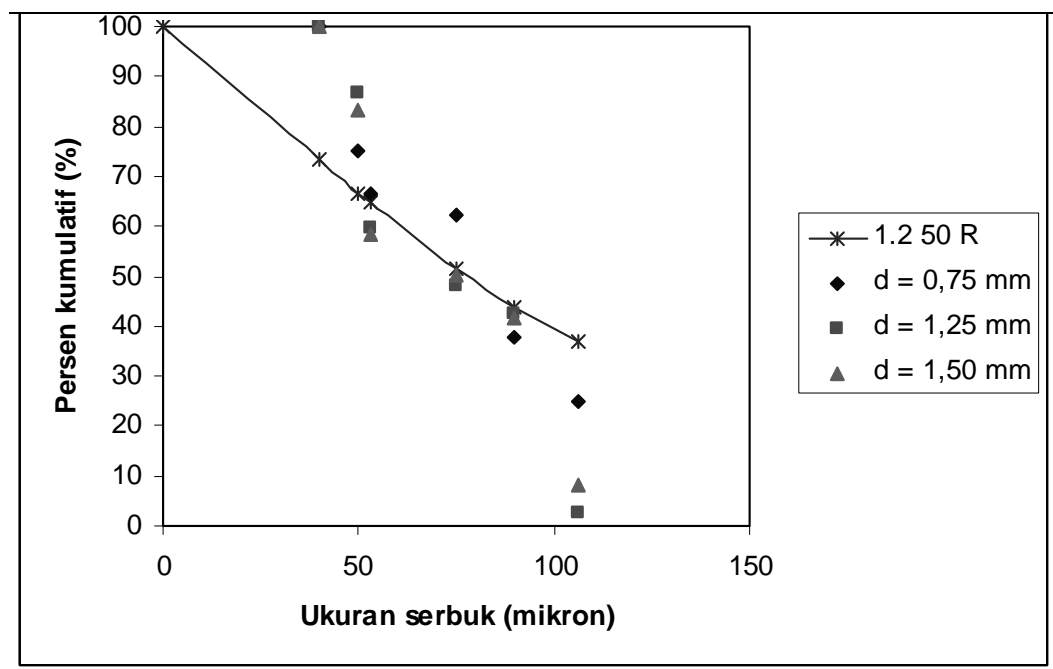

Gambar 5. Grafik distribusi persen kumulatif ukuran serbuk dengan menggunakan distribusi Rosin-Rammler-Sperling dengan nilai $\mathrm{n}=1,2$ dan $\mathrm{d}^{\prime}=106 \mathrm{~mm}$

\subsection{Proses Atomisasi dengan Variasi Sudut Serang Nosel Las}

Sudut serang adalah sudut yang dibentuk oleh nosel las dengan kawat. Dalam penelitian ini, parameter yang divariasikan adalah sudut serang, yaitu 25o, 30o, 35o, 40o, dan 45o. Sedangkan untuk parameter-parameter yang lain dibuat tetap yaitu sebagai berikut : diameter kawat 1,25 mm, panjang kawat $10 \mathrm{~m}$, jumlah nosel las 2 buah, dan jenis nyala api las nyala netral. Hasil pengujian ayakan dari serbuk hasil proses atomisasi las oksi-asitilen ini seperti pada Tabel 3. Grafik efisiensi dan laju produksi proses atomisasi las oksi-asitilen dengan variasi sudut serang nosel las dapat dilihat pada Gambar 6 dan Gambar 7.

Tabel 3. Hasil pengujian pengayakan untuk proses atomisasi dengan variasi sudut serang nosel las

\begin{tabular}{|c|c|c|c|c|c|c|c|c|c|c|c|}
\hline \multicolumn{2}{|c|}{ Ukuran Ayakan } & \multicolumn{2}{|c|}{$25^{\circ}$} & \multicolumn{2}{|c|}{$30^{\circ}$} & \multicolumn{2}{|c|}{$35^{\circ}$} & \multicolumn{2}{|c|}{$40^{\circ}$} & \multicolumn{2}{|c|}{$45^{\circ}$} \\
\hline $\begin{array}{c}\text { Sieve } \\
\text { Size }\end{array}$ & $\begin{array}{l}\text { Diameter } \\
\text { lubang } \\
\text { (mikron) }\end{array}$ & $\begin{array}{c}\text { Berat } \\
\text { (gram) }\end{array}$ & $\begin{array}{c}\text { Kumu- } \\
\text { latif } \\
(\%)\end{array}$ & $\begin{array}{l}\text { Berat } \\
\text { (gram) }\end{array}$ & $\begin{array}{c}\text { Kumu- } \\
\text { latif } \\
(\%)\end{array}$ & $\begin{array}{c}\text { Berat } \\
\text { (gram) }\end{array}$ & $\begin{array}{c}\text { Kumu- } \\
\text { latif } \\
(\%)\end{array}$ & $\begin{array}{c}\text { Berat } \\
\text { (gram) }\end{array}$ & $\begin{array}{c}\text { Kumu- } \\
\text { latif } \\
(\%)\end{array}$ & $\begin{array}{c}\text { Berat } \\
\text { (gram) }\end{array}$ & $\begin{array}{c}\text { Kumu- } \\
\text { latif } \\
(\%)\end{array}$ \\
\hline$>300$ & $<50$ & 1.19 & 10.8 & 2.01 & 13.2 & 1.62 & 11.1 & 1.48 & 12.3 & 0.79 & 9.3 \\
\hline 300 & 50 & 1.79 & 27.0 & 2.51 & 29.6 & 2.35 & 27.3 & 1.94 & 28.3 & 1.21 & 23.6 \\
\hline 270 & 53 & 0.79 & 34.1 & 1.10 & 36.8 & 1.05 & 34.6 & 0.95 & 36.2 & 0.58 & 30.5 \\
\hline 200 & 75 & 0.34 & 37.2 & 0.51 & 40.2 & 0.57 & 38.5 & 0.46 & 40.0 & 0.34 & 34.5 \\
\hline 170 & 90 & 2.24 & 57.5 & 2.92 & 59.3 & 3.34 & 61.5 & 2.59 & 61.5 & 1.77 & 55.4 \\
\hline 140 & 106 & 0.13 & 58.7 & 0.23 & 60.8 & 0.18 & 62.7 & 0.15 & 62.7 & 0.14 & 57.1 \\
\hline 120 & 125 & 4.56 & 100.0 & 5.98 & 100.0 & 5.42 & 100.0 & 4.50 & 100.0 & 3.63 & 100.0 \\
\hline & otal & 11.04 & & 15.26 & & 14.53 & & 12.07 & & 8.46 & \\
\hline
\end{tabular}




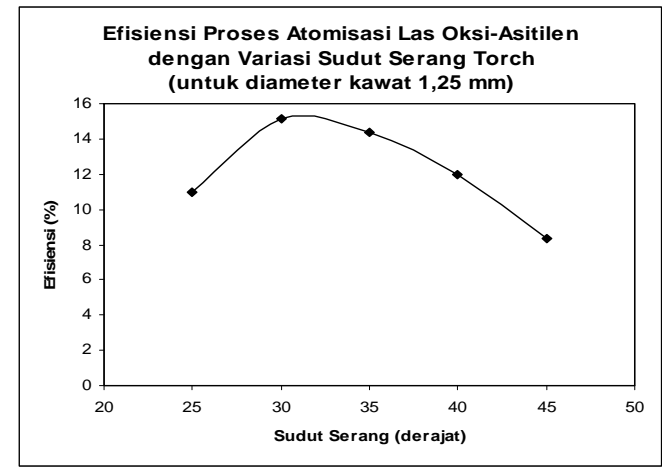

Gambar 6. Efisiensi proses atomisasi dengan variasi sudut serang

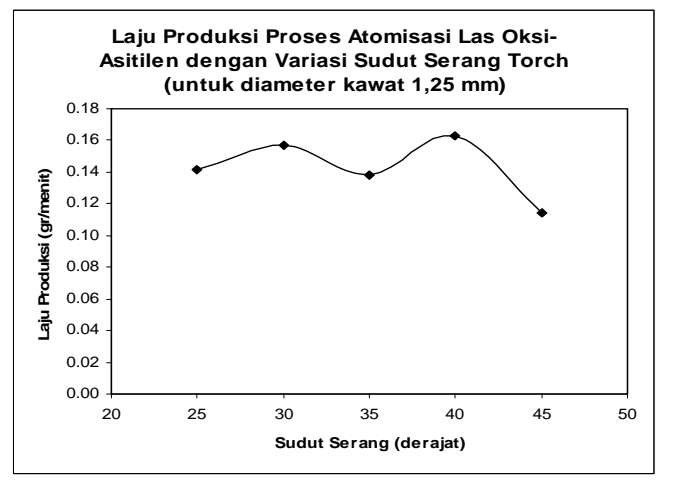

Gambar 7. Laju produksi proses atomisasi dengan variasi sudut serang

Pada sudut serang 25\% efisiensinya rendah, yaitu 10,9\%. Hal tersebut dikarenakan kawat terlalu berdekatan dengan nyala las sehingga kawat terkena radiasi panas yang cukup besar sebelum mencapai titik atomisasi, seperti pada Gambar 8. Akibatnya pada saat mencapai titik atomisasi, banyak logam cair yang menetes atau tidak teratomisasi karena terlalu banyak logam cair yang berada pada ujung kawat.

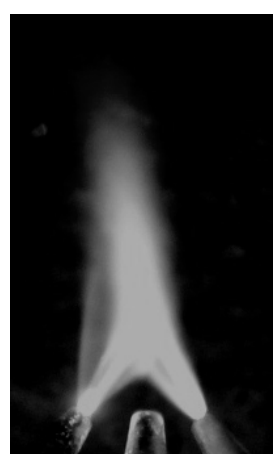

a. $\alpha=25^{\circ}$

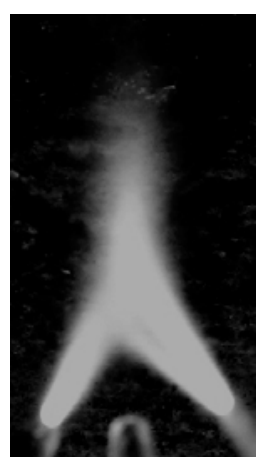

b. $\alpha=30^{\circ}$

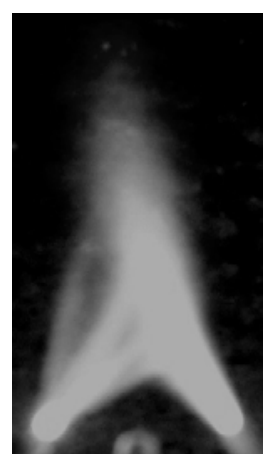

c. $\alpha=35^{\circ}$

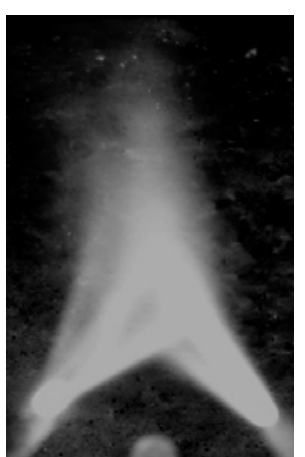

d. $\alpha=40^{\circ}$

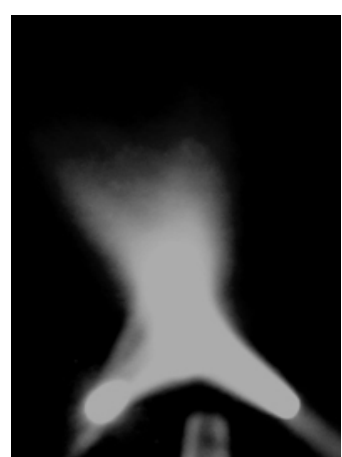

e. $\alpha=45^{\circ}$

Gambar 8. Nyala las pada sudut serang (a). $25^{\circ}$, (b). $30^{\circ},(\mathrm{c}) \cdot 35^{\circ},(\mathrm{d}) \cdot 40^{\circ},(\mathrm{e}) \cdot 45^{\circ}$

Pada sudut serang $30^{\circ}$ dihasilkan serbuk terbanyak yaitu 15,26 gram dengan efisiensi tertinggi yaitu $15,1 \%$. Pada sudut serang $30^{\circ}$ dihasilkan serbuk terbanyak yaitu 15,26 gram dengan efisiensi tertinggi yaitu 15,1\%. Dengan bertambahnya sudut serang, efisiensinya menurun dikarenakan nyala las kurang terfokus atau melebar, hingga pada sudut $45^{\circ}$ nyala las mulai bersilangan menyebabkan tekanan dari nyala las tersebar sehingga daya atomisasinya berkurang. Pada Gambar 8 dapat dilihat nyala api pada sudut $25^{\circ}, 30^{\circ}, 35^{\circ}, 40^{\circ}$, dan $45^{\circ}$. 
Berdasarkan hasil pengujian ayakan dari serbuk yang dihasilkan dari proses atomisasi dengan variasi sudut serang nosel las, seperti pada Tabel 3, dapat dibuat distibusi persen ukuran partikel menggunakan fungsi distribusi Rosin-RammlerSperling (RSS), seperti pada Gambar 9 di bawah ini :

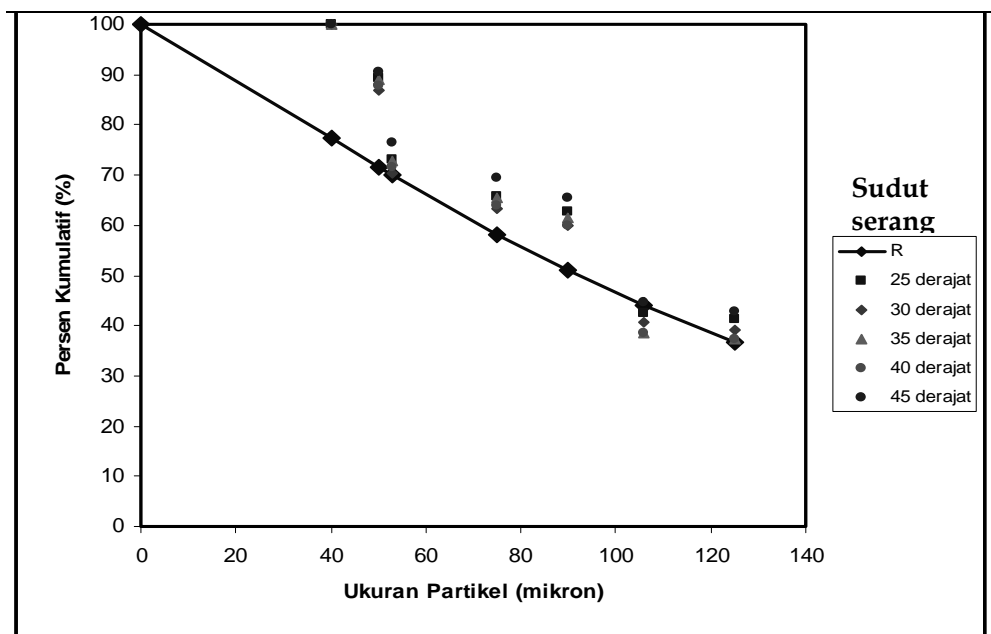

Gambar 9. Distibusi persen ukuran partikel dengan menggunakan fungsi distribusi Rosin-Rammler-Sperling (RSS)

\subsection{Komposisi Kimia Serbuk}

Hasil pengujian komposisi kimia material awal kawat dan serbuk hasil proses atomisasi yang dilakukan dengan menggunakan XRD (X-Ray Diffractometer) dapat dilihat pada Gambar 10.

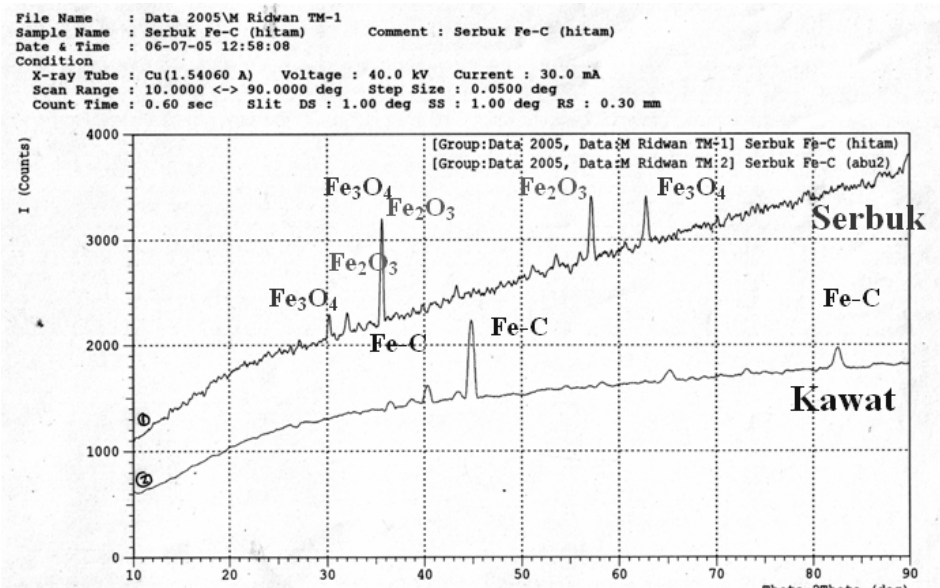

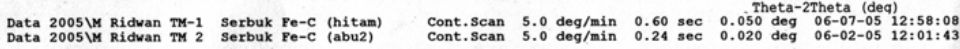

Gambar 10. Analisa komposisi kimia kawat dan serbuk hasil atomisasi menggunakan XRD 
Berdasarkan hasil pengujian ini, dengan melihat tiga puncak utama (three major peak), bahan baku kawat memiliki komposisi kimia Fe-C atau kawat baja. Sedangkan komposisi kimia serbuk yang dihasilkan oleh proses atomisasi ini adalah $\mathrm{Fe}_{2} \mathrm{O}_{3}$, dan $\mathrm{Fe}_{3} \mathrm{O}_{4}$. Hal tersebut menunjukkan bahwa selama proses atomisasi logam cair mengalami proses oksidasi. Selain itu serbuk juga mengalami proses karburasi, hal tersebut ditunjukkan oleh warna serbuk berwarna lebih hitam dibandingkan material awal yang berwarna kelabu.

\subsection{Hasil Pengujian SEM}

Pada Gambar 11, serbuk yang dihasilkan oleh proses atomisasi plasma gas oksi-asitilen, dilihat menggunakan Scanning Electron Microscope, memiliki bentuk bola (spherical) dan permukaan yang halus. Proses atomisasi ini juga dapat menghasilkan serbuk dengan ukuran yang kecil yaitu $12 \mathrm{~mm}$, seperti yang terlihat pada Gambar 11. Bentuk serbuk bola dan permukaan yang halus baik digunakan untuk pembuatan produk dengan proses metalurgi serbuk.

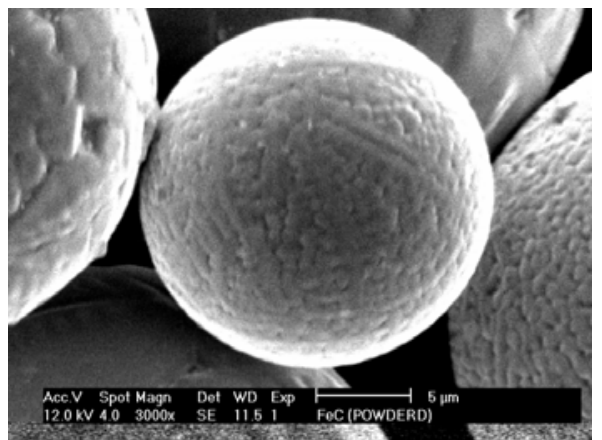

Gambar 11. Serbuk hasil atomisasi dilihat menggunakan SEM

\section{SIMPULAN}

Proses atomisasi las oksi-asitilen dapat digunakan untuk membuat serbuk logam. Serbuk logam yang dihasilkan dari proses atomisasi metoda atomisasi las oksi-asitilen ini memiliki karakteristik bentuk bola, ukuran relatif kecil yaitu antara $75 \mu \mathrm{m}-90 \mu \mathrm{m}$, permukaan halus, mengalami proses oksidasi dan proses karburasi.

Efisiensi dari proses atomisasi ini relatif masih rendah yaitu rata-rata 12,2\% dengan laju produksinya rata-rata 0,1429 gram/menit. Efisiensi dan laju produksi proses atomisasi dipengaruhi oleh diameter kawat. Diameter kawat semakin kecil maka semakin tinggi efisiensinya, namun sebaliknya laju produksinya semakin kecil. Untuk material kawat baja komersial dengan diameter 1,25 mm, proses atomisasi yang memiliki efisiensi dan laju produksi terbesar adalah menggunakan sudut serang $30^{\circ}$, yaitu $15,1 \%$ dan 0,1573 gram/menit.

\section{PUSTAKA}

[1] ASM. (2004) Handbook of Thermal Spray Technology, ASM International. Ohio.USA 
[2] Fauchais, P., Fukumoto, M., Vardelle, A., and Vardelle, M. (2004) Knowledge Concerning Splat Formation: An Invited Review, Journal of Thermal Spray Technology. Vol 13, No.3, pp 337

[3] German, M.R. (1984) Powder Metallurgy Science, Metal Powder Industries Federation. New Jersey

[4] Groover, M.P. (1996) Fundamental of Modern Manufacturing, Prentice Hall, New Jersey

[5] Harjanto, B. (2004) Pengaruh Jumlah Nosel Terhadap Karakteristik Hasil Serbuk Alumunium pada Pembuatan Serbuk Metoda Atomisasi Air, Tugas Sarjana, Teknik Mesin UGM

[6] Harpreet, S., Puri, D., and Prakash, S. (2005) Studies of Plasma Spray Coatings on a Fe-base Superalloy, Their Structure and High Temperature Oxidation Behaviour, Anti-Corrosion Methods and Materials. Vol. 52, No. 2, February 2005, pp. 84-95

[7] Kadyrov, V. K. and Getman, O. I. (2001) High-Velocity Flame Spraying of Powder Aluminium Protective Coatings, Journal of Powder Metallurgy and Metal Ceramics. Vol. 40, No. 3-4, pp 121-126

[8] Kharitonov, A. V. and Sheikhaliev, S. M. (1985) Production of Metal Powders from Melts by Centrifugal Atomization, Journal of Powder Metallurgy and Metal Ceramics. Vol. 24, No. 12, pp 883-887

[9] Lelyukh, I. M. (1993) Performance from Using Stainless-Steel and Melybdenum Materials for Gas-Thermal Deposition, Journal of Powder Metallurgy and Metal Ceramics. Vol. 32, No. 1, pp. $92-94$

[10] Litte, R. (1976) Welding and Welding Technology. McGraw-Hill. New York

[11] Mikli, V., Kaerdi, H., Kulu, P., and Besterci, M. (2001) Characterization of Powder Particle Morphology, Proceeding Estonian Academic Science Engineering. Vol. 7, No.1, pp 22-34

[12] Pawlowski, L. (1995) The Science and Enginnering of Thermal Spray Coatings, John Wiley \& Sons Ltd. England

[13] Putimtsev, B. N. (1972) Manufacture of Atomized Iron Powders Alloyed with Alumunium and Silicon, Journal of Powder Metallurgy and Metal Ceramics. Vol. 11, No. 11, pp 863-866

[14] Schiefler, M. F. O. F., Buschinelli, A. J. A., Gartner, F., Kirsten, A., Voyer, J., and Kreye, H. (2004) Influence of Process Parameters on The Quality of Thermally Sprayed X46Cr13 Stainless Steel Coatings, Journal of Brazilian Society of Mechanical Science and Engineering. Vol. 26, No. 1, Rio de Janerio

[15] Shi, S. and Hwang, J.Y. (2003) Plasma Spray Fabrication of Near-Net-Shape Ceramic Objects, Journal of Minerals and Materials Characterization and Engineering. Vol 2, No.2, pp 145-150

[16] Stanford, M. K., DellaCorte, C., and Eylon, D. (2002) Particle Size Effect on Flow Properties of PS304 Plasma Spray Feedstock Powder Blend, Nasa/TM - 2002-211550

[17] Ternovoi, Y. F., Tsipunov, A. G., Kuratchenko, S. B., Kuimova, O. M., and Kondakova, K. V. (1985) Pore Formation in Atomized Powders, Journal of Powder Metallurgy and Metal Ceramics. Vol. 24, No. 1, pp 10-13 